\title{
Knowledge Enhancement and Mitigation Strategy of Volcano Eruption Disaster Based using Macromedia Flash Media
}

\author{
Thoha Mustofa ${ }^{1}$, Chatarina Muryani ${ }^{2}$, and Yasin Yusup ${ }^{3}$ \\ \{thoha.student@gmail.com ${ }^{1}$, chatarinamuryani@staff.uns.ac.id ${ }^{2}$ \& yyfgeo@gmail.com ${ }^{3}$ \} \\ ${ }^{1,2,3}$ Pascasarjana Universitas Sebelas Maret, Surakarta, Indonesia
}

\begin{abstract}
Merapi is the most active mountain in the world that is essential to develop a learning medium of volcanic eruption disaster mitigation to clarify the material presented. This research is a research and development. It aimed to investigate the effectiveness of Macromedia flash based learning media. The development phase used the ADDIE model. The findings indicate that Macromedia flash based learning media are suitable to be used as learning media. This can be seen from: first, the material expert's validation, which obtained an average of $83.4 \%$ and the media expert's validation, which obtained $82.42 \%$ with a very appropiate category. Second, the teacher's response to the learning, which obtained a very appropiate with the percentage of the material indicator of $85 \%$, the interest of $86.6 \%$, and the suitability of the media with the material of $85 \%$; and third, the students' responses indicate that the media indicators obtained $87.5 \%$ with very appropiate categories, while media indicators and readability obtained $70 \%$ with appropiate categories. Macromedia flash-based learning media effectively increase the knowledge of the volcanic eruption disaster with an increase in learning outcomes in the experimental class of 6.25 while the increase in the control class is 2.7 .
\end{abstract}

Keywords: learning media, volcano, macromedia flash

\section{INTRODUCTION}

Mount Merapi is known as the most active volcano in the world. Cause it erupts frequently, with an average interval between eruptions, in the last century, of less than 7 years [1]. In 2010, an unusually large magnitude explosive eruption caused over 350 fatalities [2]. As an active volcano, further large explosive eruptions of Merapi should be anticipated by studying its characteristics from historical events [3].

The reduction of disaster risk becomes the Indonesian government's long-term program starts at various levels, local and national. Central to disaster risk management is facilitating disaster preparedness at national, local, community and personal levels [4]. One of the targets of disaster risk reduction is School Based Preparedness [5]. The choice of school community as a strategy for disaster risk reduction is according to the priorities of Hyogo Framework is to use knowledge, innovation and education to build a culture of safety at all levels [6]. In addition, education is a key mechanism through which children can participate in disaster risk 
reduction [7]. So, at this level mitigation strategies and risk adaptation becomes an important foothold in building a resilient community of disasters in the future. To reduce the risk of volcanic eruptions in the education sector is by improving the quality of learning. Government Regulation No. 19 Year 2005 on the Indonesian National Standard of Education that the process of learning in the educational unit organized in an interactive, inspiring, fun, challenging, motivating the students to participate actively [8]. One of the ways to improve the quality of learning is the use of learning media. Media of learning is a technology that brings message used for learning needs [9], besides multimedia animation can contain words, pictures, sounds, images, and moving pictures [10] so, it can attract students' attention to learn. Macromedia Flash 10.0, which is proven to be nvery successful and illustrative for creating multimedia applications [11]. Departing from this subject matter, learning media based on macromedia flash is more reliable in learning. Macromedia flash is a software program is able to present visual clearly to students and abstract material can be illustrated more interestingly to students with various animated images [12].

Building a resilient community of disasters at the classroom level is a tactical step continually sought by various groups. For this reason, learning that specifically addresses the mitigation strategies and natural disaster adaptation through the realm of learning media development is expected to continue to build resilient generations to future disasters. The purpose of this study are to compile a decent, affectife and efficient geographic learning media in volcanic disaster mitigation. The second is to know the effectiveness of macromedia flash geography learning media on disaster knowlegde.

\section{METHOD}

This research was conducted at SMA N 1 Cepogo, Cepogo District, Boyolali Regency of Central Java. The choice of this location is a strategic step considering that SMA Negeri Cepogo 1, Boyolali Regency is located in a prone zone of moderate level volcanic eruptions [13]. This research uses research and development method [14]. The results of this development are geography learning based on macromedia flash 8 on the subject matter of mitigation and volcanic disaster adaptation. The procedure of developing learning media uses the ADDIE model (Analyze, Design, Development, Implementation, and Evaluation) [15].

The examining of the validity of the media uses a technique of rating scale of 5-1. The feasibility conversion of learning media uses the classification proposed by Arikunto, which are $<20 \%$ of a Very inappropriate category, 21 - $40 \%$ of an inappropriate category, $41-60 \%$ is an appropriate enough category, $61-80 \%$ of an appropriate category and $81-100$ of a very appropriate categoryt [16].

The development of the ADDIE model was collaborated by the quasi experimental method with the design of the pre-test and post-test The aim is to determine the effectiveness of geography learning media based on macromedia flash in increasing students' knowledge of volcanic eruptions [17].

The product specifications are 1) Product design uses software of macromedia flash 8 on geographic subjects of class $\mathrm{X}$ with the subject matter of mitigation and natural disaster adaptation. 2) The geography learning media based on macromedia flash developed provides interesting features, including usage instructions, student attractors in the form of images, animations, back sound and explanatory texts. 3) Learning media equipped by exercises.

Processing and data analysis uses descriptive statistical methods. Descriptive statistical analysis is used to describe data in table form. The processing of this data can be completed by the help of the SPSS 20 for windows program. 


\section{RESULT AND DISCUSSION}

This research successfully developedlearning mediawith mitigation material of volcano disaster based on macromedia flash. Learning media was arranged in sequence: cover design, the volcano hazard, mitigation strategy of volcano disaster, agencies related to volcano disaster, and the last wast test.

This research was in line 2018 Chatarina Muryani research which entitled "the importance learning multimedia to enhance student praperedness". The research was focused on the discussion of eruption multimedia learning which took videos and photos from phenomenom of the Merapi mountain eruption to describe the impact and mitigation efford/ community adaption to volcano eruption.

The development step of learning media based macromedia flash can be seen as follows.

\subsection{Analys}

The results of the need analysis of learning media on geography teachers are to know effective and efficient learning media. The media must be effective and efficient because geography learning hours is very limited, only 3 hours per week. The analysis results of the student needs produce learning media is liked by student namely learning media accompanied by pictures and videos so students easily understand the learning material presented. The analysis results of the teacher and student were used as considerations to create a learning media based on macromedia flash. Macromedia flash is chosen as a learning media because it is easy to develop and effective in learning Because the ability of macromedia flash can load a variety of graphic models both text, images, videos and animations are more varied.

\subsection{Design}

The design of learning media is to design the materials of volcanic disaster mitigation into the software of macromedia flash 8 . This design includes the stages of cover design, design of material content and design of exercises. The results of learning media based on macromedia flash can be seen in the picture below.

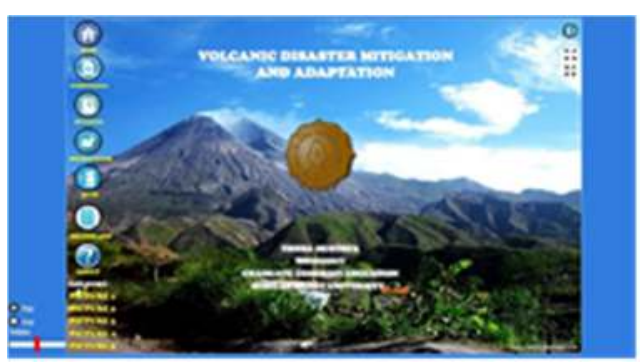

Figure 1. Design of Cover

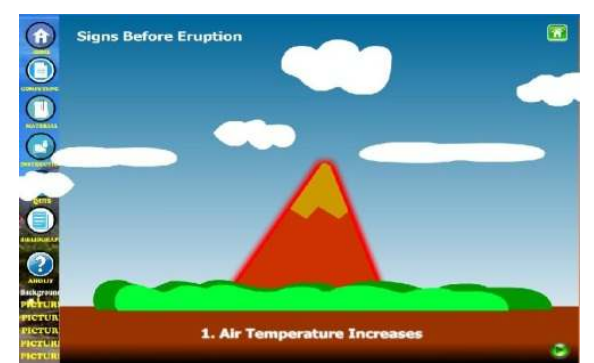

Figure 2. Design Material

Cover design is the early stage as a description can interpret summary of content contained in the learning media. The cover design contains the learning media title, university logo, main menu, developer name, background and back sound.

Material presentation includes image design, animated video equipped by explanatory information and motion animation to clarify the purpose of the material presented. The 
material presentation such as figure 2 illustrates that when a volcano will erupt the air temperature rises. An increase of air temperature is illustrated by an illustration of a reddishcolored volcano.

\subsection{Development}

The development stage in this study is testing media prototypes by experts and practitioner. The validation results of the learning media by the validation of media experts, material experts, responses by geography teachers and small group tests are presented in the figure below.

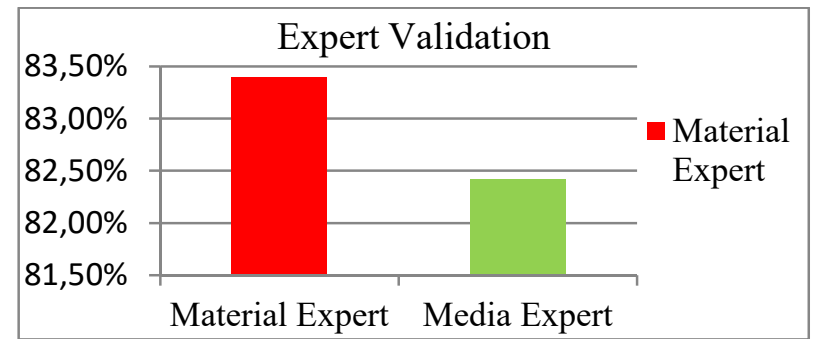

Figure 3. Results of media validation by material experts and media experts

Figure 3 shows the results of material expert validation of $83.4 \%$ with a very appropriate category and media expert validation got a percentage of $82.42 \%$ with a very appropriate category. Thus, the geography learning media based on macromedia flash can be tested to the next stage.

After the learning media was validated by material experts and process learning media experts, the next process was the appropriate test by the geography teacher. The appropriate test uses a 5-1 scale, or it is very appropriate until it is not appropriate. The results of the appropriate test can be seen in figure 4 .

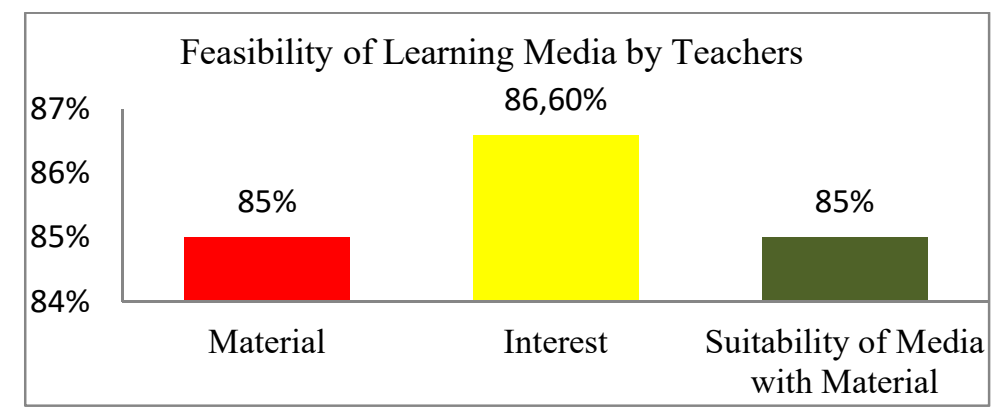

Figure 4. Results of teacher responses of the appropriate of macromedia flash media

The geography teacher's response shows that the learning media has a very appropriate category because the percentage of material indicators is $85 \%, 86.6 \%$ interest and $85 \%$ of the media compatibility with the material.

The next stage is a small group test conducted on class X IPA 1 with number of 10 students by the students are given exposure of geography learning media based on macromedia flash, then students assess the appropriateness of media with material indicators, media and readability of learning media. 


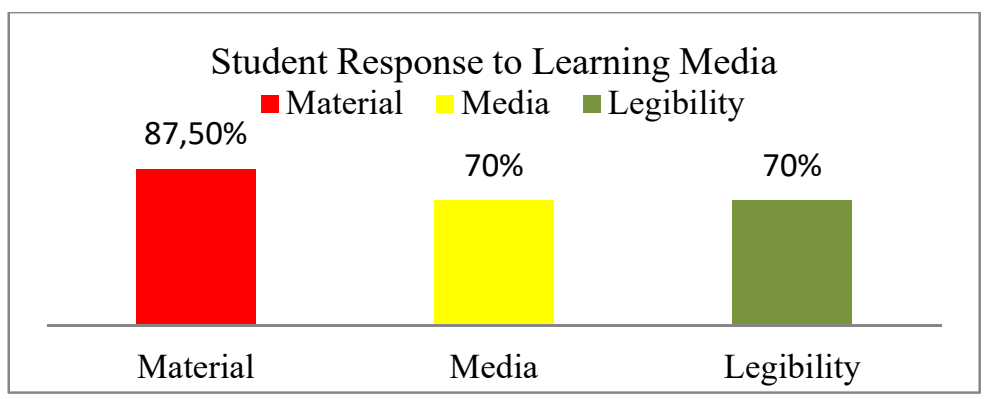

Figure 5. Results of student responses to the appropriateness of the use of media

Small group test results illustrate that the material indicator reaches the percentage of $87.5 \%$ with a very appropriate category, while the media indicator and the readability of each of them get a percentage of $70 \%$ has a category of appropriate categories. In other words, media is appropriate for advanced learning.

The learning media has been revised and fulfilled the eligibility requirements by material experts, media experts, geography teachers and small group tests then carried out further stage, namely learning media implemented as teaching media to increase students' knowledge of volcanic eruptions.

\subsection{Implementation}

The results of the implementation of the application based on macromedia flash aim to determine the effectiveness of learning media on disaster knowledge. The results of field tests on disaster knowledge variables were carried out in class X IPA 3 as the experimental group and in class X IPA 2 as the control group. At the pretest and post test used 20 items of multiple choice questions, previously they had been tested for validity, reliability, level of difficulty and differentiation of questions. The results of each experimental class and control class can be seen in table 2 .

Table 1. Results of tabulation of pre-test and post-test of experimental class and disaster knowledge variable control class

\begin{tabular}{llcccc}
\hline \multicolumn{5}{c}{ Paired Samples Statistics } \\
\hline \multirow{2}{*}{ Pair 1 } & Mean & $\mathrm{N}$ & Std. Deviation & Std. Error Mean \\
& pretest_eksperimen & 9,80 & 20 & 1,576 &, 352 \\
\multirow{2}{*}{ Pair 2 2} & posttest_eksperimen & 16,05 & 20 & 2,502 &, 559 \\
& pretest_kontrol & 10,45 & 20 & 1,356 &, 303 \\
& posttest_kontrol & 13,15 & 20 & 1,694 &, 379 \\
\hline
\end{tabular}

The results of table 1 show that the knowledge of the experimental class and the control class after the pre-test and post-test of each class had increased learning outcomes. Disaster knowledge in the experimental class experienced a significant increase where the mean in the pre-test results got a mean of 9.80 and when the post-test means the experimental class was 05.05 with a mean increase of 6.25 . Whereas in the control class when the pre test was carried out the mean was 10.45 and in the post test the mean was 13.15 in other words an increase in the mean of the control class 2.7. So it can be concluded that the learning media application of macromedia flash in the experimental class is more effective in increasing volcanic disaster knowledge than the control class. 
The result of this researc was same with the 2018 Chatarina Muryani research which entitled "the importance learning multimedia to enhance student praperedness". The reaserch was focussed on the discussion of eruption multimedia learning showed that learn used multimedia eruption learning was more effective to improve student readiness towards disaster than who did not use multimedia.

\subsection{Evaluation}

This evaluation consists of, first evaluation the analysis phase. At the needs analysis stage, it should not only analyze the needs of teachers and students, curriculum analysis and analysis of classroom learning should be carried out so that researchers know better media to develop. Second, evaluate the implementation phase. The lack of research time requires researchers to only test products to one class, namely class X IPA 3 as the experimental class and class X IPA 2 as the control class.

\section{CONCLUSION}

First, the appropriate stages of learning media are material expert validation, media validation, media appropriate test by the teacher, and small group test. Results of material expert validation get a percentage of $83.4 \%$ and the validation of expert media gets a percentage of $83.43 \%$ with each category gets very appropriate. The teacher's response to geography learning media is geografy learning media based on macromedia flash is very appropriate to be used as teaching material with evidence of percentages on material indicators of $85 \%, 86.6 \%$ interest and $85 \%$ media suitability with appropriate categories. The results of the acquisition in the small group test are the percentage of the material indicator to $87.5 \%$ with a very appropriate category, while the media indicator and the readability of each get a percentage of $70 \%$ have an appropriate category. Thus it can be concluded that learning media based on macromedia flash are appropriate as learning media.

Second, geography learning media based on macromedia flash increases the knowledge of students of class X of SMA Cepogo 1 on volcanic eruption disasters where the experimental class pre test gets a mean of 9.80 and when the post test means the experimental class is 05.05 with an increase in mean of 6,25 . Whereas in the control class when the pre test was carried out the mean was 10.45 and in the post test the mean was 13.15 in other words an increase in the mean of the control class 2.7 .

\section{REFERENCE}

[1] A. Ratdomopurbo et al., "Overview of the 2006 eruption of Mt. Merapi," J. Volcanol. Geotherm. Res., vol. 261, pp. 87-97, 2013.

[2] E. T. W. Mei et al., "Lessons learned from the 2010 evacuations at Merapi volcano," $J$. Volcanol. Geotherm. Res., vol. 261, pp. 348-365, 2013.

[3] Jumadi, A. Heppenstall, N. Malleson, S. Carver, D. Quincey, and V. Manville, "Modelling Individual Evacuation Decisions during Natural Disasters: A Case Study of Volcanic Crisis in Merapi, Indonesia," Geosciences, vol. 8, no. 6, p. 196, 2018.

[4] S. Sagala, N. Okada, and D. Paton, "Predictors of intention to prepare for volcanic risks in Mt Merapi, Indonesia,” J. Pacific Rim Psychol., vol. 3, no. 2, pp. 47-54, 2009.

[5] K. P. Bencana, Kerangka Kerja Sekolah Siaga Bencana. Jakarta: Konsorsium Pendidikan Bencana Indonesia, 2011.

[6] F. Kagawa and D. Selby, “ Ready for the Storm: Education for Disaster Risk Reduction 
and Climate Change Adaptation and Mitigation 1 ," J. Educ. Sustain. Dev., vol. 6, no. 2, pp. 207-217, 2013.

[7] C. Muryani, Y. Yusup, and S. Prihadi, "The Importance of Disaster Learning Multimedia To Enhance Studentsr Preparedness,” 2018, vol. 262, no. Ictte, pp. 153-156.

[8] M. Simbolon, E. Surya, and E. Syahputra, "The Efforts to Improving the Mathematical Critical Thinking Student' s Ability through Problem Solving Learning Strategy by Using Macromedia Flash,” Am. J. Educ. Res., vol. 5, no. 7, pp. 725-731, 2017.

[9] U. Ramadhan, C. Muryani, and S. Nugraha, "Development of Geography E-Learning Media Based Adobe Flash to Improve Studenrt Learning Outcome of 10th Grade in Senior High School 1 Sragen," 2018, vol. 262, no. Ictte, pp. 144-148.

[10] C. C. Chiou, L. C. Tien, and L. T. Lee, "Effects on learning of multimedia animation combined with multidimensional concept maps," Comput. Educ., vol. 80, pp. 211-223, 2015.

[11] M. Milovanovi and M. J. Obradovic, "Aplication Of Imteractive Multimedia Tools In Teaching Mathematics - Examples Of Lesson From Geometry,” vol. 12, no. 1, pp. 1931, 2013.

[12] I. N. C. Mukti and H. Nurcahyo, "Pengembangan Media Pembelajaran Biologi Berbantuan Komputer untuk Meningkatkan Hasil Belajar Peserta Didik * Corresponding Author.Email: intanncmukti1@gmail.com Developing Computer- Based Biology Learning Media to Improve the Students 'Learning Outcom,” vol. 3, no. 2, pp. 137-149, 2017.

[13] S. Triutomo and T. W. Sudinda, Indeks Rawan Bencana Indonesia. Jakarta: BNPB, 2011.

[14] A. H. Saragih, "Development of Character-Based Instructional Model through Constructivism Approach in Lesson Study," in 2nd Annual International Seminar on Transformative Education and Educational Leadership (AISTEEL 2017), 2017, no. September, pp. 209-234.

[15] M. Mayfield, "Creating training and development programs: Using the ADDIE method," Dev. Learn. Organ., vol. 25, no. 3, pp. 19-22, 2011.

[16] S. Arikunto, Prosedur Penelitian, Edisi Revi. Yogyakarta: Rineka Cipta, 2009.

[17] I. P. A. A. Payadnya and I. G. A. N. T. Jayantika, Panduan Penelitian Eksperimen Beserta Analisis Statistik dengan SPSS. Yogyakarta: Deepublish, 2018. 